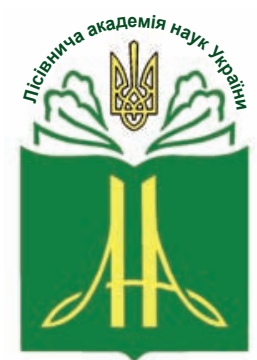

Forestry Academy of Sciences of Ukraine
Наукові праці Лісівничої академії наук України Proceedings of the Forestry Academy of Sciences of Ukraine http://fasu.nltu.edu.ua https://doi.org/10.15421/412109

Article received 2021.02.03

Article accepted 2021.06.10
ISSN 1991-606X print

ISSN 2616-5015 online

(a) $\square$ Correspondence author

Svitlana Los

svitlana_los@ukr.net
Pushkinska str., 86, Kharkiv, 61024, Ukraine

\title{
Популяційна мінливість морфологічних ознак жіночих репродуктивних органів Quercus robur L. у Лісостепу та Степу України
}

\author{
С. А. Лось ${ }^{1}$
}

Наведено результати вивчення популяиійної мінливості Quercus robur L. y Лicocmeny ma Cmепy за довжиною плодоніжки, ї̈ формою та кількістю жолудів на ній. Досліджено 18 деревостанів природного та штучного походження у Харківській, Полтавській, Луганській, Донецькій і Кіровоградській областях. Деревостани природного походження представлені лісовими генетичними резерватами, итучного - переважно постійними лісонасінними ділянками. Зразки заготовляли під кронами дерев у кількості 30-100 штук (залежно від урожаю жолудів - по 1-2 з дерева) у кожному обстеженому виділі. Для порівняння мікропопуляцій за комплексом морфологічних і біометричних показників використано графічний метод побудови зображень морфотипів у програмі MC EXEL. Визначено рівні внутрішньо- та міжпопуляційної мінливості.

У природних деревостанах Харківської, Донецької і Луганської областей переважали дерева, для яких характерні плодоніжки завдовжки 2,1-5,0 см, тоді як у деревостанах природного походження в Кіровоградській області-5,1-8,0 см. У насадженнях шттучного походження на Кіровоградщині представлені дерева як з короткими, так і довгими плодоніжками.

Виявлено регіональні особливості щзодо прялизни плодоніжки: у природних деревостанах Харківщчини переважали дерева із прямими плодоніжками, а на Кіровоградщині - з дещо викривленими. Серед штучних насаджень були такі, в яких переважали дерева з прямими плодоніжками (п'ять деревостанів), зі злегка викривленими плодоніжками (два деревостани) та з рівною часткою дерев обох ичих груп (один деревостан). У природних деревостанах Харківщчини та Донеччини переважали дерева з одним жолудем на плодоніжці, тоді як $у$ природних деревостанах Кіровоградщини частоти трапляння дерев з одним та двома жолудями на плодоніжизі приблизно однакова. У більшості штучних деревостанів Кіровоградщчини переважали дерева з одним жолудем на плодоніжиі.

У переважній більшості випадків недорозвинених зав'язей на плодоніжках не відзначено. Частка дерев, на плодоніжках яких було по одній недорозвиненій зав'язі, становила від 10,0 до 33,3\%.

Рівень внутрішньопопуляиійної мінливості за всіма показниками - від високого до дуже високого, міжпопуляційної-середній.

Для природних деревостанів Quегсиs robur L. у Харківській, Донеиькій та Луганській областях характерне переважання дерев з відносно короткими прямими плодоніжками й одним жолудем на ній, тоді як у Кіровоградській - середньої довжини та з двома жолудями. Встановлено збільшення довжини плодоніжки та кількості жолудів на ній у напрямку зі сходу на захід. Штучним деревостанам притаманний вищции рівень мінливості за всіма показниками порівняно з природними.

Ключові слова: популяція; мінливість; плодоніжка; жолудь; зав'язь; бал; морфотип.

Лось Світлана Анатоліївна - член-кореспондент Лісівничої академії наук України, кандидат сільськогосподарських наук, завідувачка лабораторії селекції. Український науково-дослідний інститут лісового господарства та агролісомеліорації ім. Г.М. Висоцького, вул. Пушкінська, 86, м. Харків, 61024, Україна. Тел.: 057-707-80-77, +38-097-138-97-92. E-mail: svitlana_los@ukr.net ORCID: https:// orcid.org/0000-0002-6341-2745 
Вступ. Рід Quercus вирізняється великою кількістю видів (Малеев, 1936; Меницкий, 1984; Nixon, 2002; Denk, Grimm, Manos, Deng, \& Hipp, 2017; Tantray, \& Wani, 2017) і природних міжвидових гібридів (Rushton, 1993). Для визначення таксонів, разом з молекулярно-генетичними методами, досі $є$ актуальним використання морфологічних характеристик видів і форм. При цьому важливо визначити найвагоміші 3 них, що мають найвищу «розрізнювальну силу» між таксонами (Enescu, 2017). Ceред багатьох морфологічних ознак представників роду Quercus для визначення видів одними 3 найважливіших вважають довжину плодоніжки (Малеев, 1936; Nixon, 2002; Mehrnia, Nejadsattari, Assadi, \& Mehregan, 2013; Aykut, Emel, \& Tekin, 2017). Так, за результатами досліджень, проведених у 20 дубових деревостанах Quercus pubescens Willd. та Quercus virgiliana (Ten.) Ten. у Румунії, серед декількох морфологічних характеристик найбільшу «розрізнювальну силу» показала саме ця ознака (Enescu, Curtu, \& S,ofletea, 2013). При складанні дихотомічного ключа для визначення цих видів, серед інших важливих показників було названо довжину плодоніжки і зазначено, що це - єдина ознака, за якою розрізняють дуби пухнастий та віргінський (Enescu, 2017). Ï̈̈, разом з іншими морфологічними характеристиками, використовують для визначення не лише цих видів та їхніх гібридних форм (Dupouey 1983).

Дуже часто ознаку довжини плодоніжки використовують для розрізнення двох деревних видів Quercus robur L. i Quercus petreaea L. (Dupouey, 1983; Dupouey, \& Badeau, 1993). Відомо, що дуб звичайний вирізняється відносно довгою плодоніжкою, а дуб скельний - дуже короткою або її взагалі немає (синонімічна назва - дуб сидячоцвітий (Quercus sessiliflora Salisb.).

Для дуба звичайного характерний високий внутрішньовидовий поліморфізм, зокрема і за довжиною плодоніжки, що підтверджено науковцями різних країн. Так, аналізуючи морфологічні характеристики звичайного та скельного дубів у Великій Британії, Шотландії та Югославії J.Е. Cousens (1965) зазначав, що показники довжини плодоніжки дуба звичайного змінюються у межах від 1,0 до 4,0 см у Шотландії, до 9,0 см у Югославії і до 12,0 см у Великій Британії. Для дуба звичайного за цим показником виділяють декілька форм. У насадженнях України їх представленість найширше розглянуто у роботі В.М. Андрєєва (1927), яка і донині не втратила актуальності. Найпоширенішою є форма $f$. typica Beck. (1890), у якої довжина плодоніжки дорівнює половині довжини листка. Також виділяють форми з короткою плодоніжкою f. brevipes Beck. (1890) $(<2 \mathrm{~cm})$ та f. pseudosessilis A. et G. (1857) (0,6-1,2 см). Першу форму зафіксував в районі Святогорська проф. В.М. Черняєв (1867) (Харківська область), а В.М. Андрєєв - у насадженнях Велико-Анадольського, Старобердянського лісництв (1926) (Донецька область) та в дендрологічних парках. Форму $f$. pseudosessilis A. et G. (1857) було відзначено на Волині, у Рівненській і Сумській областях. Крім того, відомі форми f. australis Gurke. (1897), у якої плодоніжка дорівнює довжині листка та $f$. longipedunculata Gurke. (1897), у якої плодоніжка перевершує довжину листка. У представників $f$. australis зазвичай формується декілька жолудів (іноді 6-8 штук) і плодоніжка сягає іноді 1317 см. Наявність цієї форми відзначали А. С. Мачинський у Тростянецькому л-ві на Сумщині і П. С. Погребняк на Волині. Форму $f$. longipedunculata, для якої характерна довжина плодоніжки до 16,5-25 см, описав П.С. Погребняк (1926) у Тростянецькому лісництві. За спостереженнями цього науковця, форми з короткими плодоніжками трапляються в Україні частіше, ніж з довгими. Також відзначено, що форми 3 довгими плодоніжками мають більшу кількість жолудів на них. У багатьох публікаціях (Погребняк, 1926; Мачинський, 1927; Кривошея, 1969; Кучеревский, 1988) описано форми дуба звичайного з різною довжиною плодоніжки. Водночас більшість подібних досліджень засвідчує наявність певних форм, не аналізуючи їх представленість у певних деревостанах або географічних регіонах.

Незважаючи на те, що морфологічні особливості дуба звичайного досліджують від початку XX століття, у більшості робіт під час вивчення морфології репродуктивних органів розглядають переважно розміри та форму жолудів. Так, аналізуючи популяційну мінливість цього виду, Л.Ф. Семеріков (1986) надає лише середні показники обстежених популяцій у східній частині ареалу (Верхнього Дону, Заволжя та південного Уралу), які змінюються у межах від 25 до 53,3 мм.

Серед сучасних популяційних досліджень дуба звичайного в Україні варто відзначити роботу А.А. Слєпих та I. I. Коршикова (2017), які вивчали формове різноманіття жолудів на заповідних лісових територіях Донеччини. Автори відзначали високе варіювання довжини плодоніжки. Максимальний показник перевищував мінімальний в 1,2-5 разів. Для дерев дуба звичайного у деревостанах НПП «Святі гори», заповідника «Крейдяна флора» та заказника «Великоанадольський ліс» характерні плодоніжки завдовжки 38-43 мм, тоді як у РЛП «Донецький кряж», «Краматорський», «Клебан-бик» $\mathrm{i}$ заказник «Азовська дача»-28-30 мм.

Показникам кількості та розташування жолудів i недорозвинених зав'язів на плодоніжці науковці приділяють мало уваги. Лише у роботі (Nixon, 1993) подано класифікацію роду Quercus за розташуванням на плодоніжках недорозвинених жолудів. Разом $з$ тим, за результатами наших попередніх досліджень морфологічної мінливості плюсових дерев і клонів Quercus robur L. у Харківській області (Лось, Борисова, 2002) та на Поділлі (Los \& Smachnuk, 2020), вони найбільше відрізнялися за довжиною плодоніжки, показниками ії форми та кількості жолудів і недорозвинених зав'язів на ній, i саме ці ознаки було запропоновано використовувати для ідентифікації клонів. Довжина плодоніжки обстежених плюсових дерев і клонів на Поділлі 
становила у середньому від 2,2 до 8,5 см, а кількість жолудів - від 1,0 до 2,5 штук.

Здійснені дослідження розширюють наявні дані щодо внутрішньо- та міжпопуляційної мінливості дуба звичайного за низкою важливих морфологічних ознак репродуктивних органів дерев, що може бути використано під час уточнення лісонасінного районування та розроблення стратегій збереження генофонду виду.

Об'єкти та методика досліджень. Об ' $\epsilon$ ' сліджень - фенотипова мінливість жіночих репродуктивних органів Quercus robur L. Предмет досліджень - характер мінливості природних і штучних мікропопуляцій Quercus robur L. за довжиною та формою плодоніжки, кількістю жолудів та недорозвинених зав'язів.

Мета роботи - проаналізувати мінливість природних і штучних мікропопуляцій Quercus robur L. у Лісостепу і Степу за довжиною і формою плодоніжки та кількістю жолудів і недорозвинених зав'язів на ній.

Дослідження здійснено у 18-ти деревостанах дуба звичайного - переважно у Лісостепу (Кіровоградська, Полтавська, Харківська області). Декілька деревостанів обстежено у степовій частині Кіровоградської, Луганської і Донецької областей (табл. 1, рис. 1). Деревостани природного походження представлені лісовими генетичними резерватами (ЛГР), штучного - переважно постійними лісонасінними ділянками (ПЛНД). У деяких випадках обстеженнями охоплені 2-3 сусідні виділи або квартали. Кожен обстежений деревостан розглядали як мікропопуляції. Зразки плодоніжок заготовляли під кронами дерев загалом по 30-100 штук, залежно від урожаю жолудів, у кожному обстеженому виділі.

Таблицяя 1

Коротка характеристика обстежених деревостанів дуба звичайного

\begin{tabular}{|c|c|c|c|c|}
\hline \multicolumn{2}{|c|}{ Місце розташування деревостану } & \multirow{2}{*}{$\begin{array}{l}\text { Вік, } \\
\text { років }\end{array}$} & \multirow{2}{*}{ Походження } & \multirow{2}{*}{$\begin{array}{c}\text { Статус об’ єкта } \\
\text { ПЛНБ }\end{array}$} \\
\hline Лісництво & Квартал/виділ & & & \\
\hline \multicolumn{5}{|c|}{ Кіровоградська область, ДП «Олександрівське лісове господарство } \\
\hline 1. Бірківське & $27 / 3$ & 108 & штучне & ЛГР \\
\hline 2. Червоно-Нерубаївське & $57 / 1$ & 111 & природне & ЛГР \\
\hline 3. Червоно-Нерубаївське & $64 / 1$ & 146 & природне & ЛГР \\
\hline 4. Червоно-Нерубаївське & $90 / 4$ & 138 & штучне & ПЛНД \\
\hline 5. Червоно-Нерубаївське & $90 / 5$ & 138 & штучне & Плнд \\
\hline 6. Червоно-Нерубаївське & $90 / 6$ & 138 & штучне & ПЛНД \\
\hline \multicolumn{5}{|c|}{ Кіровоградська область, ДП «Оникіївське лісове господарство } \\
\hline 7. Ново-Українське & $7 / 8$ & 87 & штучне & ПЛНД \\
\hline \multicolumn{5}{|c|}{ Кіровоградська область, ДП «Чорноліське лісове господарство» } \\
\hline 8. Богданівське & $42 / 1$ & 87 & штучне & ПЛНД \\
\hline 9. Чутянське & $38 / 3$ & 109 & штучне & ПЛНД \\
\hline 10. Чутянське & $40 / 1$ & 106 & природне & ЛГР \\
\hline \multicolumn{5}{|c|}{ Полтавська область, ДП «Гадяцьке лісове господарство } \\
\hline 11. Вельбівське & $151 / 1$ & 106 & штучне & ПЛНД \\
\hline 12. Краснолуцьке & $50 / 4$ & 76 & штучне & ПЛНД \\
\hline \multicolumn{5}{|c|}{ Харківська область, НПП «Гомільшанські ліси» } \\
\hline 13. Гомільшанське & $37 / 1$ & 147 & природне & ЛГР \\
\hline 14. Гомільшанське & $38 / 1$ & 152 & природне & ЛГР \\
\hline 15. Гомільшанське & $43 / 2$ & 142 & природне & ЛГР, ПН \\
\hline \multicolumn{5}{|c|}{ Харківська область, ДП «Вовчанське лісове господарство» } \\
\hline 16. Хотомлянське & $94 / 1$ & 133 & природне & ЛГР \\
\hline \multicolumn{5}{|c|}{ Донецька область, ДП «Слов’янське лісове господарство» } \\
\hline 17. Маяцьке & $34 / 2$ & 121 & природне & ЛГР \\
\hline \multicolumn{5}{|c|}{ Луганська область, ДП «Новоайдарське лісове господарство» } \\
\hline 18. Слов'яносербське & 107,108 & 117 & природне & ЛГР \\
\hline
\end{tabular}


Дослідження виконано в кожному деревостані одноразово з огляду на те, що за спостереженнями минулих років на КНП показники кількості жолудів і недорозвинених зав'язів на окремій плодоніжці для клонів досить стабільні ознаки (Лось, Борисова, 2002). Погодні умови, безумовно, впливають на рясність плодоношення, але у дуба це спричиняє зменшення або збільшення кількості суцвіть і суплідь на окремій гілці і як наслідок - у кроні дерева.

Для кожної плодоніжки визначено чотири показники - довжину, прямизну, кількість розвинених жолудів та кількість недорозвинених зав'язей на ній (Los \& Smachnuk, 2020). Довжину плодоніжки вимірювали лінійкою. Вибірки обраховували методами варіаційної статистики з використанням пакету програм MC EXEL. Аналізували також розподіл значень ознак для кожної мікропопуляції. 3 огляду на високий рівень варіювання (коефіцієнти варіації для більшості вибірок були понад 30\%) і обмежену можливість використання параметричної статистики, всі ознаки для кожної мікропопуляції оцінили в балах за шкалами, наведеними у табл. 2.

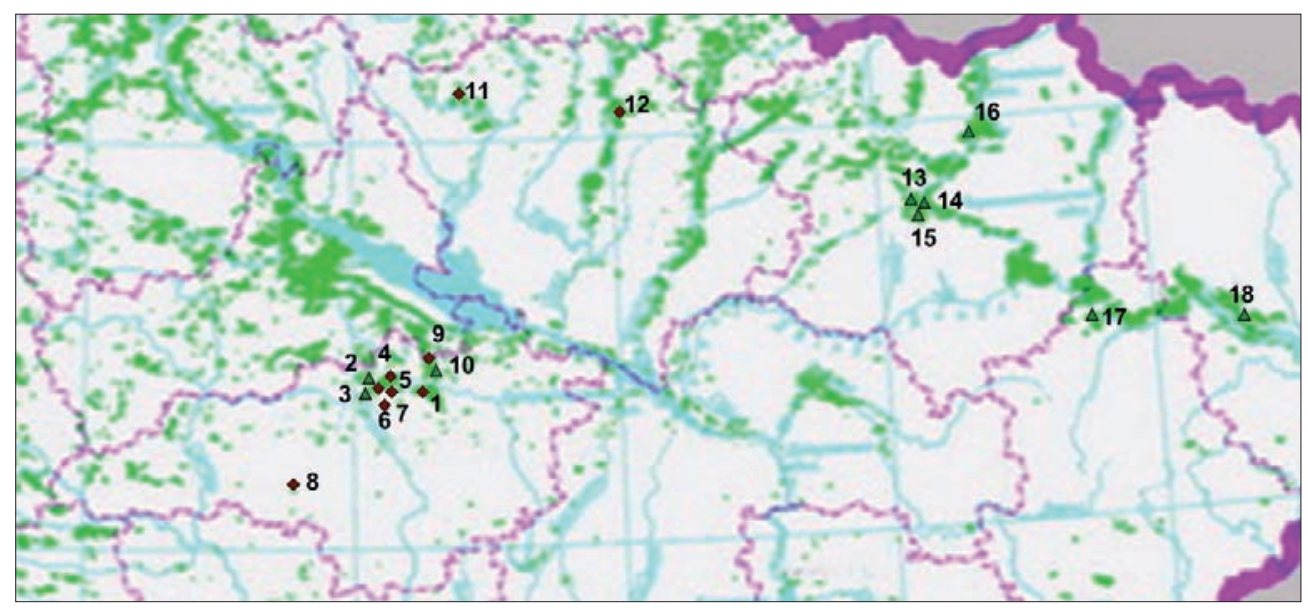

Рис. 1. Розташування обстежених деревостанів природного (А) і штучного походження $(\diamond)$ (номери згідно 3 табл. 1$)$

Таблиця 2

Балове оцінювання морфологічних показників жіночих репродуктивних органів дуба звичайного (Los \& Smachnuk, 2020)

\begin{tabular}{lccccc}
\hline \multicolumn{1}{c}{ Показник } & \multicolumn{5}{c}{ Бал } \\
\cline { 2 - 6 } & 1 & 2 & 3 & 4 & 5 \\
\hline Довжина плодоніжки (ДП) & $2,0 \mathrm{~cm}$ & $2,1-5,0 \mathrm{~cm}$ & $5,1-8,0$ см & $8,1-11,0 \mathrm{~cm}$ & $\geq 11,1 \mathrm{~cm}$ \\
\hline Прямизна плодоніжки (ПП) & пряма & $\begin{array}{c}\text { злегка } \\
\text { викривлена }\end{array}$ & $\begin{array}{c}\text { середньо ви- } \\
\text { кривлена }\end{array}$ & $\begin{array}{c}\text { викривлена } \\
\text { (колінчаста) }\end{array}$ & $\begin{array}{c}\text { дуже } \\
\text { колінчаста }\end{array}$ \\
\hline Кількість жолудів на плодоніжці (КЖ) & $1,0-1,4$ & $1,5-2,0$ & $2,1-2,5$ & $2,6-3,0$ & $>3$ \\
\hline $\begin{array}{l}\text { Кількість недорозвинених зав'язей } \\
\text { на плодоніжці (КНЗ) }\end{array}$ & $<1$ & $1,1-2,0$ & $2,1-3,0$ & $3,1-4,0$ & $>4$ \\
\hline
\end{tabular}

Рівень мінливості морфологічних ознак оцінювали за шкалою С. О. Мамаєва (Мамаев, 1972): дуже низький $(\mathrm{CV}<7 \%)$; низький $(\mathrm{CV}=8-12 \%)$; середній $(\mathrm{CV}=13-20 \%)$; підвищений $(\mathrm{CV}=21-30 \%)$; високий $(\mathrm{CV}=31-40 \%)$; дуже високий $(\mathrm{CV}>40 \%)$. Для порівняння мікропопуляцій за комплексом вивчених морфологічних та кількісних ознак використано графічний метод побудови зображень морфотипів 3 використанням кругових пелюсткових діаграм у програмі MC EXEL (Los \& Smachnuk, 2020).

Результати та обговорення. 3 огляду на те, що середній показник характеризує деревостан загалом, але не надає інформації про внутрішньопопуляційну мінливість за певною ознакою, під час аналізування передусім розглядали фактичний розподіл значень кожного з показників.
Так, розглядаючи показники довжини плодоніжки у природних деревостанах Лівобережного Лісостепу та Степу, бачимо (рис. 2, А), що в усіх шести випадках (генетичні резервати у Хотомлянському, Гомільшанському, Маяцькому та Слов'яносербському лісництвах) для більшості плодоніжок характерна довжина від 2,1 до 5,0 cм. Усі графіки розподілу дерев за цими показниками характеризуються позитивною асиметрією. Частка плодоніжок $<2$ см становила від 6,6 до $12,7 \%, 10$ $33,3 \%$ дерев мали плодоніжки завдовжки від 5,1 до 8,0 см. Частка дерев $з$ довшими плодоніжками становила менше $10 \%$. Отримані дані не суперечать результатам досліджень популяцій дуба на Донеччині (Слепых, Коршиков, 2017), які зафіксували середню довжину плодоніжки 38-43 мм. Рівень вну- 
трішньопопуляційної мінливості - високий і дуже високий $(\mathrm{CV}=38,0-87,8 \%)$.

Характер розподілу дерев за цим показником у двох штучних деревостанах Лівобережжя дуже різниться між собою (див. рис. 2, Б). Якщо розподіл показників насадження у Краснолуцькому лісництві подібний до описаних вище природних деревостанів, то насадження у Вільбівському лісництві характеризується рівними частками дерев 3 плодоніжками завдовжки 2,1-5,0 і 5,1-8,0 см (33\%). При цьому частки дерев 3 дуже короткими $(<2$ см) і довгими $(>8,0$ см) плодоніжками становлять приблизно третину від загальної кількості дерев. Рівень внутрішньопопуляційної мінливості - дуже високий $(\mathrm{CV}=49,8-49,9 \%)$. Характер розподілу дерев за цією ознакою у деревостанах генетичних резерватів природного походження на Правобережжі (Кiровоградська область) має дещо інший вигляд, ніж

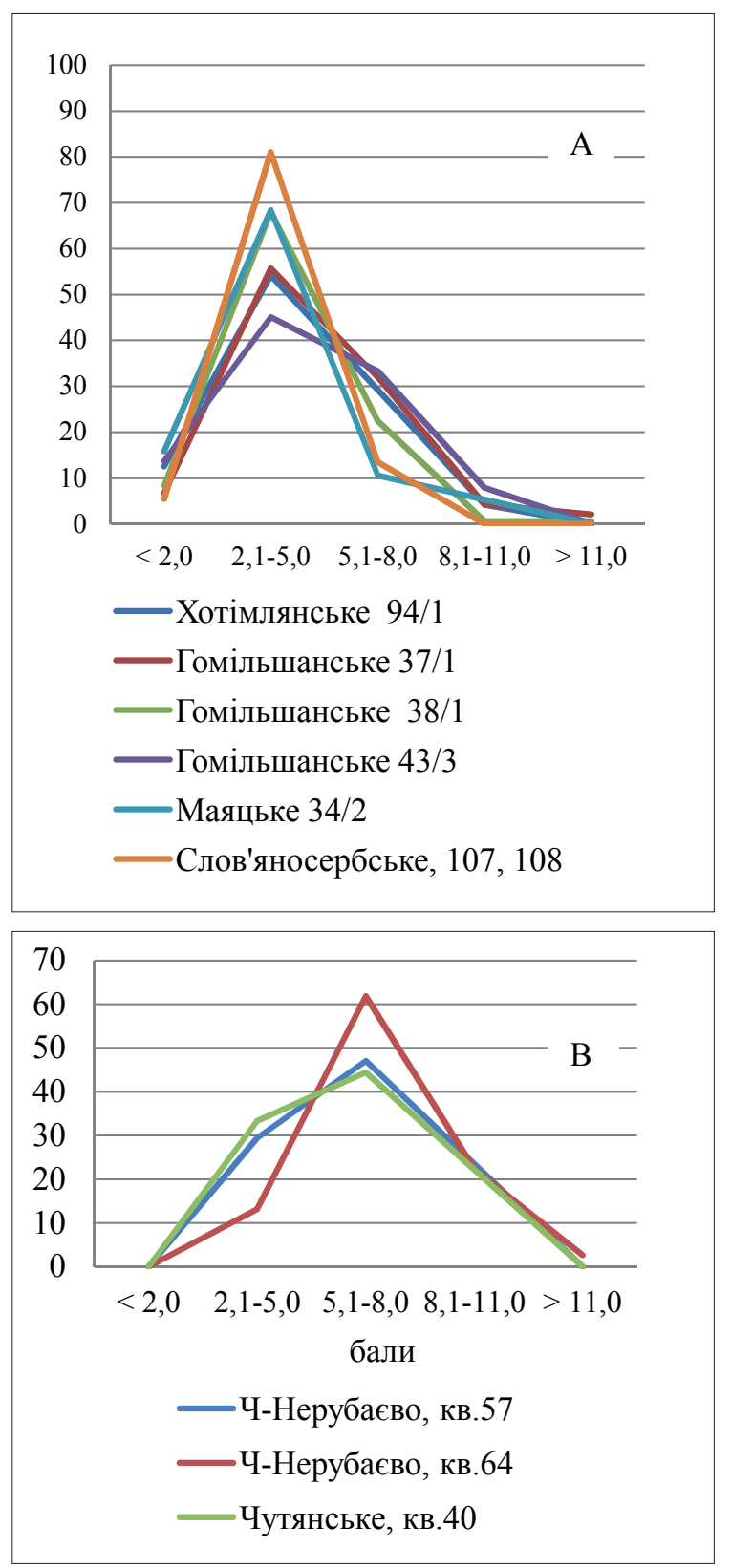

на Лівобережжі (див. рис. 2, В). Так, в усіх трьох деревостанах переважають дерева із плодоніжками завдовжки 5,1-8,0 см. Частка дерев 3 плодоніжками завдовжки від 2,1 до 5,0 см становила 13,2-33,3\%. Приблизно на такому самому рівні частка дерев 3 плодоніжками $>8,0$ см. Графіки розподілу майже симетричні, розподіл наближається до нормального. Рівень внутрішньопопуляційної мінливості високий $(\mathrm{CV}=30,0-34,0 \%)$.

Серед штучних деревостанів Кіровоградщини (див. рис. 2, Г) умовно виділено три групи:

- 3 переважанням дерев із плодоніжками завдовжки 2,1-5 см (Червоно-Нерубаївське л-во, кв. 90);

- 3 переважанням дерев із плодоніжками завдовжки 5,1-8,0 см (Бірківське, Ново-Українське і Чутянське лісництва);

- 3 рівною часткою дерев обох цих груп (Богданівське л-во).
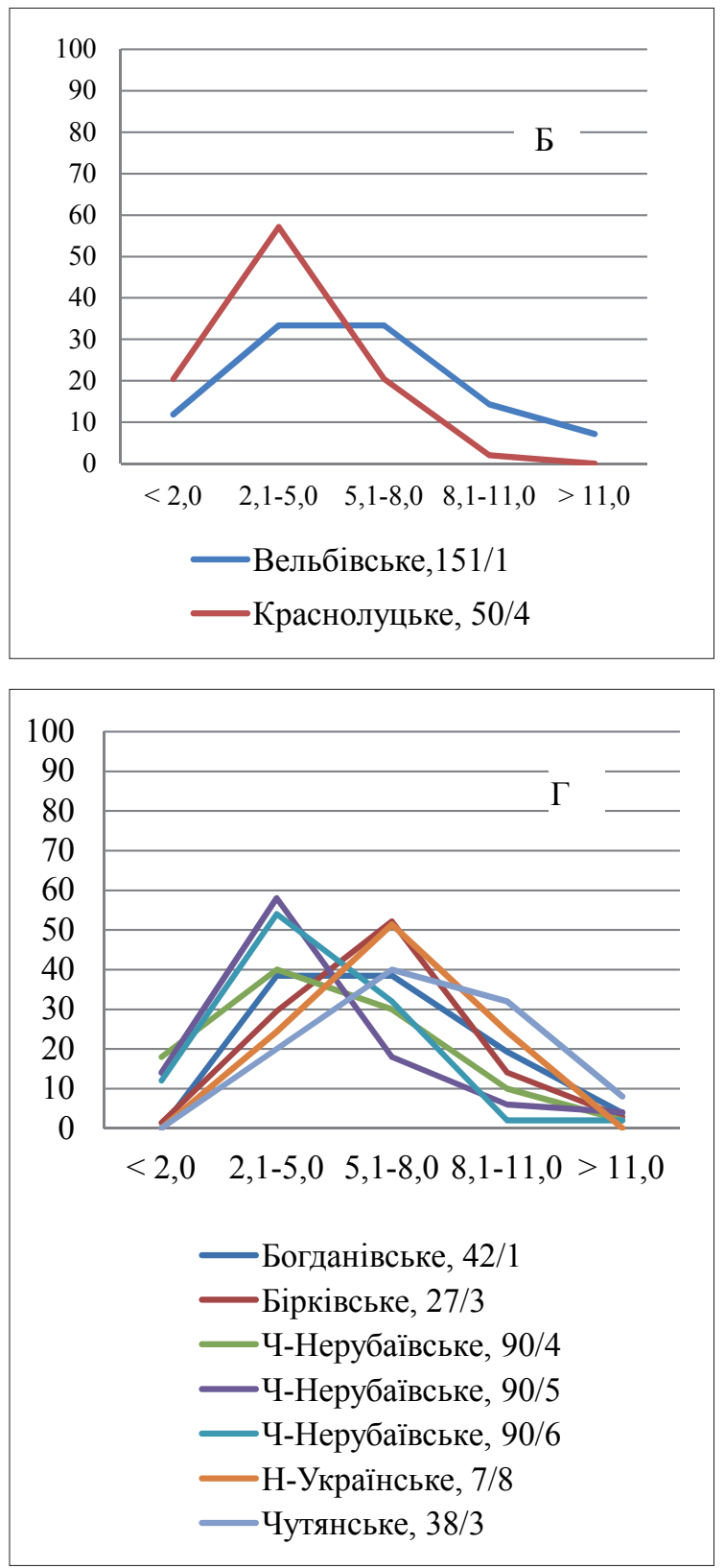

Рис. 2. Розподіл дерев у природних (А, В) і штучних (Б, Г) деревостанах за довжиною плодоніжки 
Рівень внутрішньопопуляційної мінливості переважно високий $(\mathrm{CV}=29,3-38,1 \%)$. Винятком $\epsilon$ ПЛНД у виділах 4, 5 і 6 кв. 90 Червоно-Нерубаївського лісництва, де рівень мінливості дуже високий $(\mathrm{CV}=47,4-61,3 \%)$. Водночас рівень міжпопуляційної мінливості довжини плодоніжок середній $(\mathrm{CV}=20,8 \%)$.

В усіх обстежених деревостанах траплялися дерева 3 плодоніжками різної форми - від прямої до дуже колінчастої (рис. 3). При цьому в природних деревостанах Харківщини переважали дерева із прямими плодоніжками (20,0-70,8\%), найбільшу частку яких виявлено у Хотімлянському лісництві, найменшу - у кв. 43, в. 3 Гомільшанського лісництва (рис. 3, А). В останньому деревостані відзначено і досить високу частку дерев 3 довгими плодоніжками (> 11,1 см). Рівень внутрішньопопуляційної мінливості здебільшого дуже високий $(\mathrm{CV}=$ 40,7-50,6\%).

Деревостан у Маяцькому лісництві вирізнявся дуже високою часткою дерев зі злегка викривленою плодоніжкою (60\%). У Слов'яносербському лісництві переважали дерева 3 прямими, злегка та середньо викривленими плодоніжками (див. рис. 3, А). Рівень внутрішньопопуляційної мінливості високий і дуже високий $(\mathrm{CV}=37,0$ i 45,2\%).
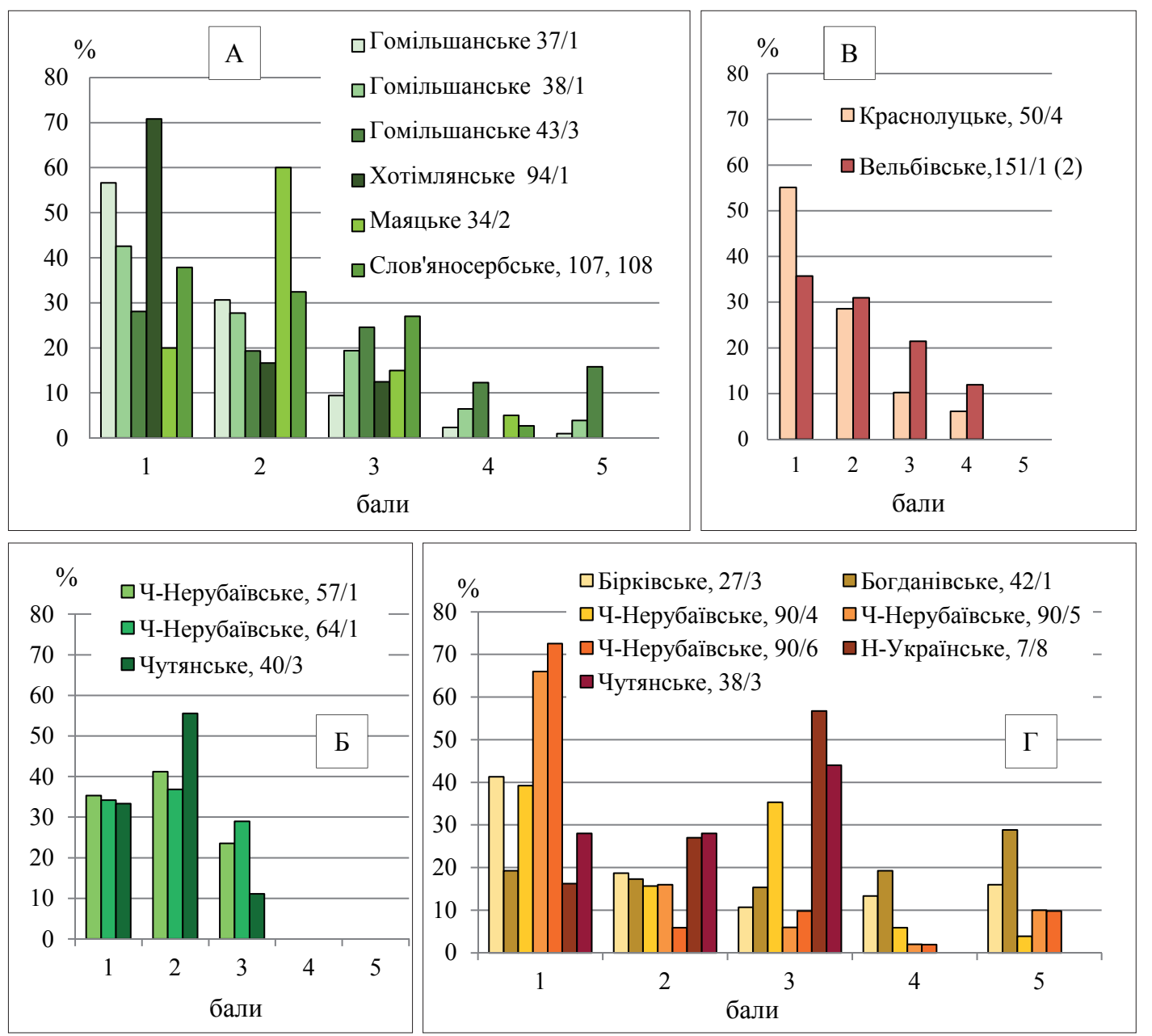

Рис. 3. Розподіл дерев у природних (А, Б) і штучних (B, Г) деревостанах за прямизною плодоніжки

Штучні деревостани Полтавщини (рис. 3, Б) вирізнялися переважанням дерев із прямими плодоніжками $(35,7$ і $55,1 \%)$. Приблизно третина дерев у них була зі злегка викривленими плодоніжками $(31,0$ і 28,6\%). Рівень внутрішньопопуляційної мінливості - від високого до дуже високого (CV = 49,2-53,7\%).

У природних деревостанах Кіровоградщини (рис. 3, В) переважали дерева зі злегка викривленою плодоніжкою. Дерева із прямими плодоніжками траплялися у $35 \%$ випадків. При цьому дерев 3 колінчастими плодоніжками не виявлено. Рівень внутрішньопопуляційної мінливості - високий і дуже високий $(\mathrm{CV}=37,5-41,5 \%)$.
Штучні деревостани Кіровоградської області (рис. $3, \Gamma$ ) за зазначеною ознакою умовно розподілено на три групи:

- 3 переважанням дерев із прямими плодоніжками у плодів (Червоно-Нерубаївське л-во, кв. 90 та Бірківське лісництво, кв 27);

- 3 переважанням плодів дерев із середньо викривленими плодоніжками (Ново-Українське, Чутянське лісництва);

- 3 рівною часткою дерев обох попередніх груп i переважанням дуже колінчастих плодоніжкок (Богданівське л-во). 
Рівень внутрішньопопуляційної мінливості - від високого до дуже високого ( $\mathrm{CV}=39,4-75,7$ \%). Piвень міжпопуляційної мінливості - середній $(\mathrm{CV}=$ $16,8 \%)$.

Кількість нормально розвинених жолудів на плодоніжках в обстежених деревостанах змінювалася від 1 до 5. При цьому розподіл за частотою трапляння як у природних, так і штучних деревостанах, на Лівобережжі був дуже подібний (рис. 4, А, Б). Переважали дерева 3 одним жолудем на плодоніжці (64,5-82,1\%). Дерева з трьома-чотирма жолудями на плодоніжці траплялися дуже рідко - переважно до 5\%. Винятком є кв. 43 у Гомільшан- ському лісництві, де відзначено 10\% таких дерев. Внутрішньопопуляційна мінливість - дуже висока $(\mathrm{CV}=41,6-58,6 \%)$.

Аналізуючи баловий розподіл показника у природних деревостанах Кіровоградщини (рис. 4, В) потрібно відзначити їхню подібність при відмінності від попередніх груп (див. рис. 4, А, Б). Зокрема, частота трапляння дерев 3 одним та двома жолудями на плодоніжці приблизно однакова, при цьому наявна незначна частка дерев 3 чотирма жолудями на плодоніжці. Рівень внутрішньопопуляційної мінливості - високий і дуже високий $(\mathrm{CV}=$ $37,5-46,7 \%)$.
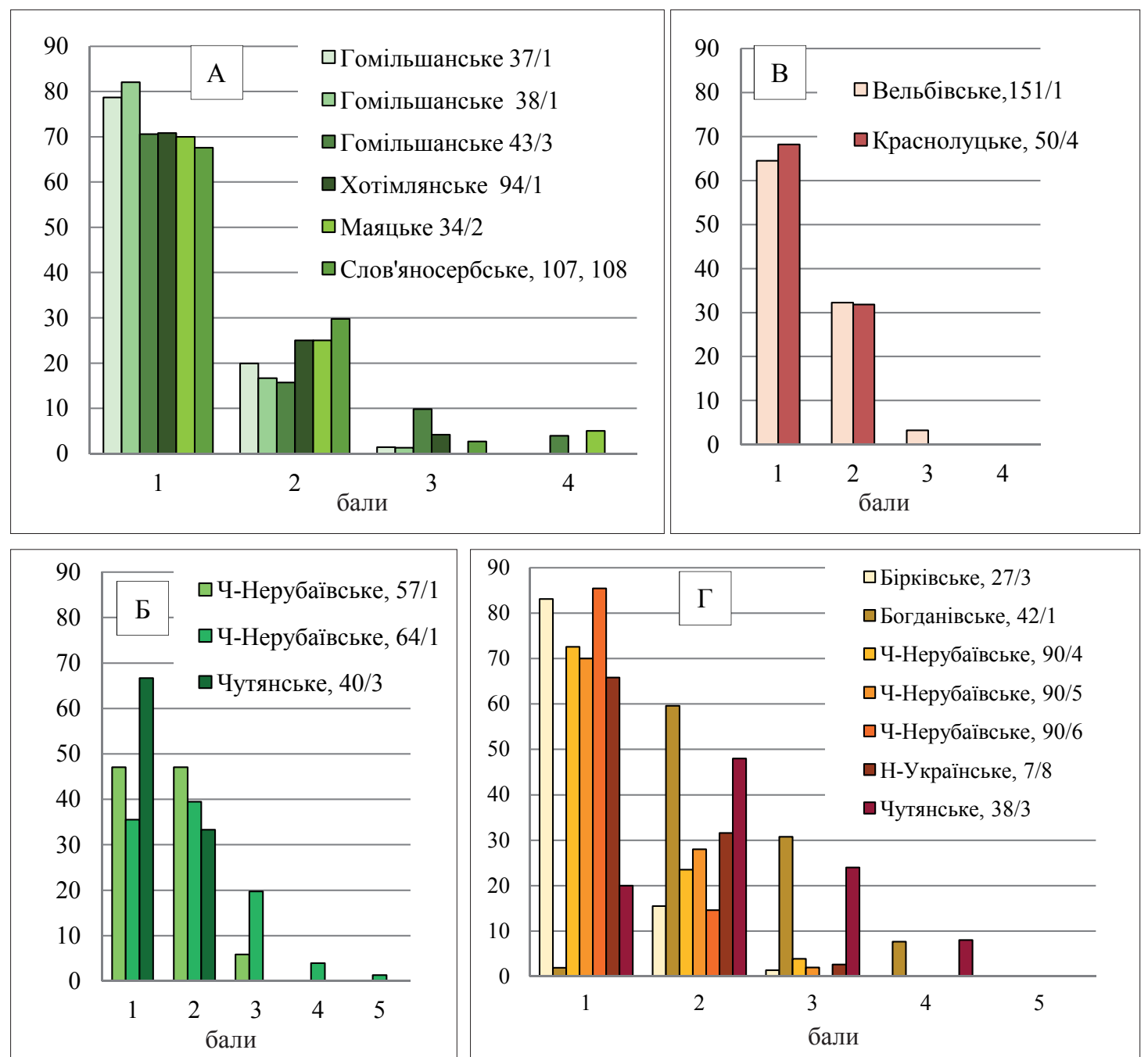

Рис. 4. Розподіл дерев у природних (А, Б) і штучних (B, Г) деревостанах за кількістю жолудів на плодоніжках (\%)

Штучні деревостани Кіровоградської області за кількістю нормально розвинених жолудів на плодоніжках різнилися (рис. 4, Г). Здебільшого в обстежених деревостанах переважали дерева з одним жолудем на плодоніжці і лише у двох (Богданівське лісництво і Чутянське лісництво, кв. 38) - із двома. Рівень внутрішньопопуляційної мінливості - високий і дуже високий $(\mathrm{CV}=31,0-46,4 \%)$. Коефіцієнт варіації між популяціями $(21,3 \%)$ вказує на підвищений рівень міжпопуляційної мінливості. Кількість недорозвинених зав'язей на плодоніжках в усіх обстежених деревостанах становила від 0 до 6 шт. (рис. 5).

Розподіл за частотою трапляння дерев 3 певною кількістю недорозвинених зав'язей на плодоніжках у всіх деревостанах досить подібний. Здебільшого на плодоніжках не було недорозвинених зав'язей. Частка дерев, на плодоніжках яких було по одній недорозвиненій зав'язі, становила від 10,0 до $37,3 \%$, а таких, на плодоніжках яких було по дві і більше зав'язей, - не перевищувала $10 \%$, за винятком чотирьох деревостанів (одного природно- 
го і трьох штучних у Кіровоградській області) (див. рис. 5). Рівень внутрішньопопуляційної мінливості - дуже високий. При цьому рівень міжпуляційної мінливості також дуже високий $(\mathrm{CV}=44,4 \%)$.

Порівняльну характеристику обстежених мікропопуляцій за чотирма показниками у балах подано у табл. 3. Для кожного обстеженого деревостану за середніми показниками, оціненими у балах, було побудовано пелюсткові діаграми морфотипів. Для деяких мікропопуляцій показники виявилися ідентичними, що дало змогу згрупувати деревостани за морфотипами (рис. 6).
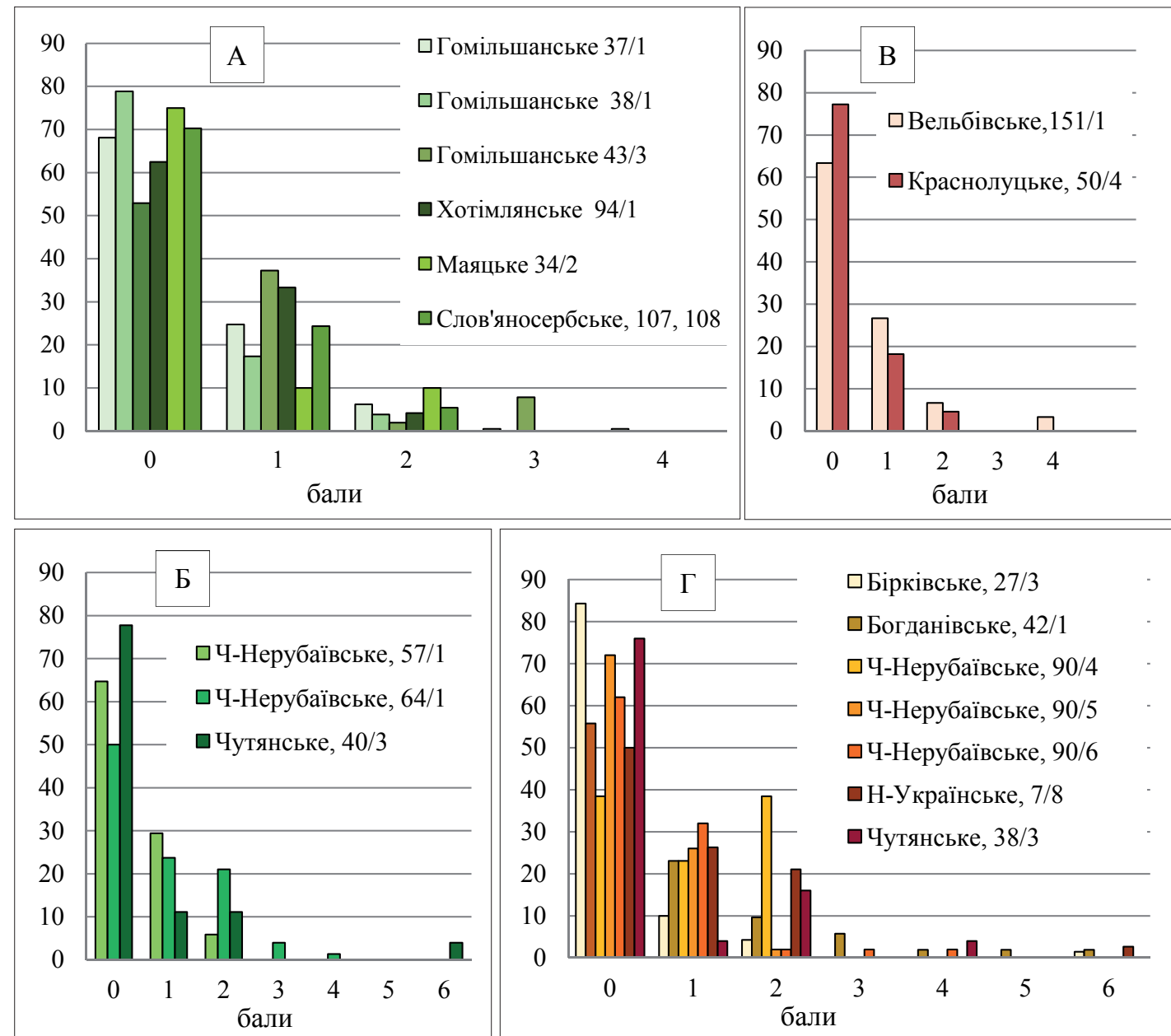

Рис. 5. Розподіл дерев у природних (А, Б) і штучних (B, Г) деревостанах за кількістю недорозвинених зав'язей на плодоніжках $(\%)$

Таблиця 3

Морфологічні характеристики обстежених мікропопуляцій у балах

\begin{tabular}{|c|c|c|c|c|}
\hline Лісництво, кв./вид. & $\begin{array}{c}\text { Довжина } \\
\text { плодоніжки, см }\end{array}$ & $\begin{array}{c}\text { Прямизна } \\
\text { плодоніжки, бали }\end{array}$ & $\begin{array}{c}\text { Кількість } \\
\text { жолудів, шт. }\end{array}$ & $\begin{array}{c}\text { Кількість недорозвинених } \\
\text { зав'язей, шт. }\end{array}$ \\
\hline 1 & 2 & 3 & 4 & 5 \\
\hline \multicolumn{5}{|c|}{ Кіровоградська область, природні деревостани } \\
\hline Червоно-Нерубаївське, 57/1 & 3 & 1 & 2 & 1 \\
\hline Червоно-Нерубаївське, 64/1 & 3 & 2 & 2 & 1 \\
\hline Чутянське, 40/3 & 3 & 2 & 1 & 1 \\
\hline \multicolumn{5}{|c|}{ Полтавська область, штучні деревостани } \\
\hline Вельбівське, 151/1 & 3 & 2 & 1 & 1 \\
\hline Краснолуцьке, 50/4 & 2 & 2 & 1 & 1 \\
\hline \multicolumn{5}{|c|}{ Кіровоградська область, штучні деревостани } \\
\hline Бірківське, 27/3 & 3 & 2 & 2 & 1 \\
\hline
\end{tabular}


Продовж. табл. 3

\begin{tabular}{lllll}
\hline \multicolumn{1}{c}{} & 2 & 3 & 4 & 5 \\
\hline Богданівське, 42/1 & 3 & 2 & 2 & 1 \\
Червоно-Нерубаївське, $90 / 4$ & 2 & 2 & 1 & 1 \\
Червоно-Нерубаївське, $90 / 5$ & 2 & 2 & 1 & 1 \\
Червоно-Нерубаївське, $90 / 6$ & 2 & 2 & 1 & 1 \\
Ново-Українське, $7 / 8$ & 3 & 3 & 1 & 1 \\
Чутянське, $38 / 3$ & 3 & 2 & 3 & 1 \\
\hline
\end{tabular}

\begin{tabular}{|c|c|c|c|c|}
\hline \multicolumn{5}{|c|}{ Харківська область, природні деревостани } \\
\hline Гомільшанське, 37/1 & 3 & 2 & 1 & 1 \\
\hline Гомільшанське, 38/1 & 2 & 1 & 1 & 1 \\
\hline Гомільшанське, 43/3 & 2 & 2 & 1 & 1 \\
\hline Хотімлянське, 94/1 & 2 & 2 & 1 & 1 \\
\hline \multicolumn{5}{|c|}{ Донецька область, природний деревостан } \\
\hline Маяцьке, 34/2 & 2 & 2 & 1 & 1 \\
\hline \multicolumn{5}{|c|}{ Луганська область, природний деревостан } \\
\hline Слов'яносербське, 107, 108 & 2 & 2 & 1 & 1 \\
\hline
\end{tabular}

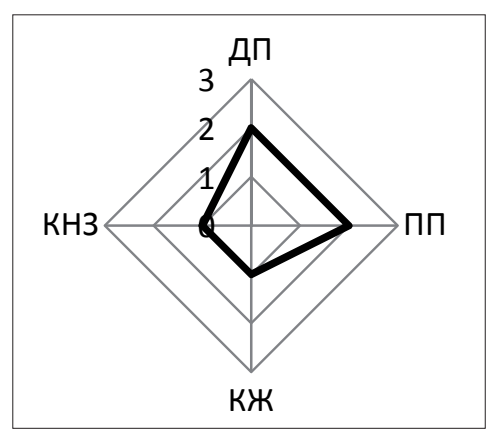

А. Гомільшанське $43 / 3$ *;

Хотімлянське 94/1 *; Маяцьке $34 / 2$ *;

Ч-Нерубаївське, 90/4, 5, 6;

Краснолуцьке, 50/4;

Слов'яносербське, 107/1 *

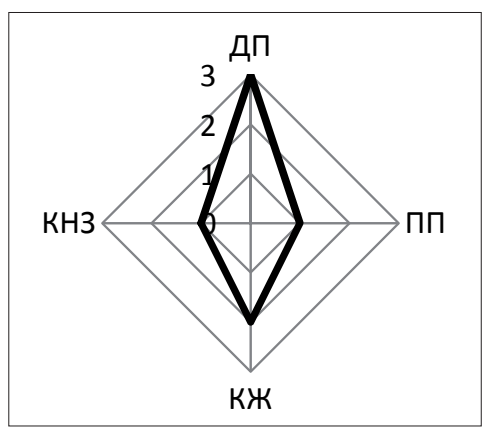

Г. Ч-Нерубаївське, 57/1 *

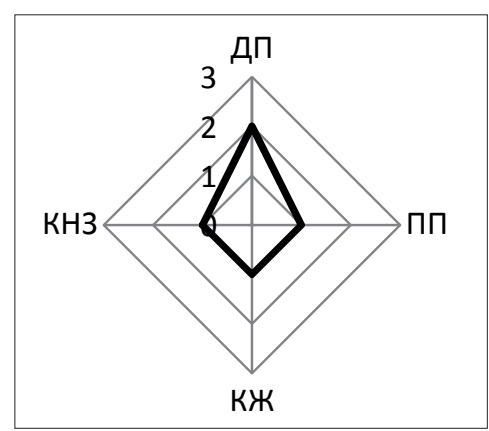

Б. Гомільшанське $38 / 1$ *

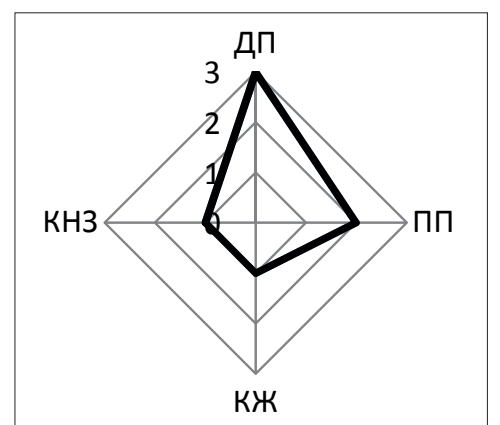

В. Чутянське, $40 / 3$ *, Гомільшанське $37 / 1$ *; Вельбівське, $151 / 1$

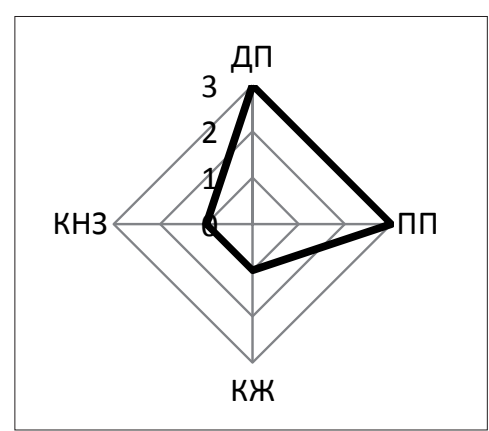

Д. Н-Українське, 7/8

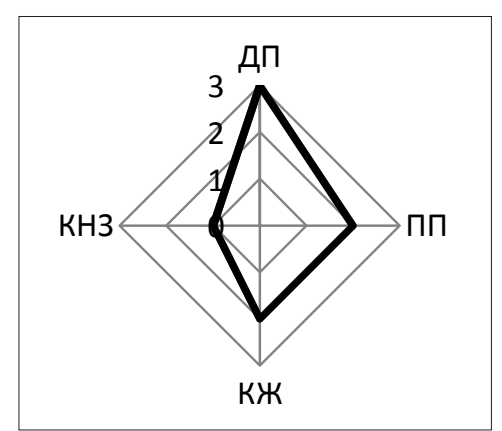

Ж. Ч-Нерубаївське, 64/ 1 * Бірківське, 27/3, Богданівське, 42/1

Рис. 6 (початок). Групування обстежених деревостанів Quercus robur L. за морфотипами 
ДП - довжина плодоніжки,

ПП - прямизна плодоніжки,

КЖ -кількість жолудів на плодоніжці,

КНЗ - кількість недорозвинених зав'язів

* - деревостани природного походження

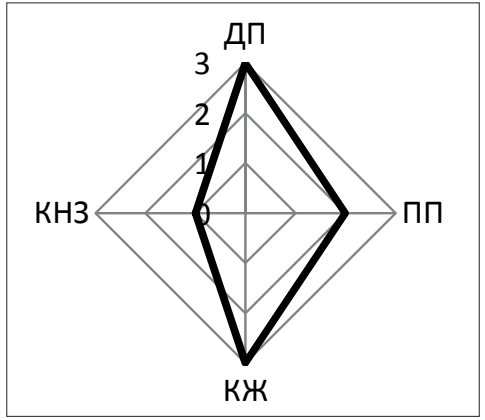

3. Чутянське, $38 / 3$

Рис. 6 (продовження). Групування обстежених деревостанів Quercus robur L. за морфотипами

Аналізуючи дані табл. 3 та рис. 6, варто відзначити, що у деревостанах природного походження Харківської області переважають дерева 3 відносно короткими прямими плодоніжками та одним жолудем на них. Тоді як для природних деревостанів Кіровоградської області характерні плодоніжки середньої довжини з двома жолудями. Для штучних деревостанів певних закономірностей не відзначе- но, але виявлено вищий рівень мінливості за всіма показниками порівняно з природними.

Накладання морфотипів природних деревостанів на карту демонструє виявлені регіональні особливості популяційного характеру (рис. 7). А саме: збільшення довжини плодоніжки та кількості жолудів на ньому у дерев з просуванням зі сходу на захід.

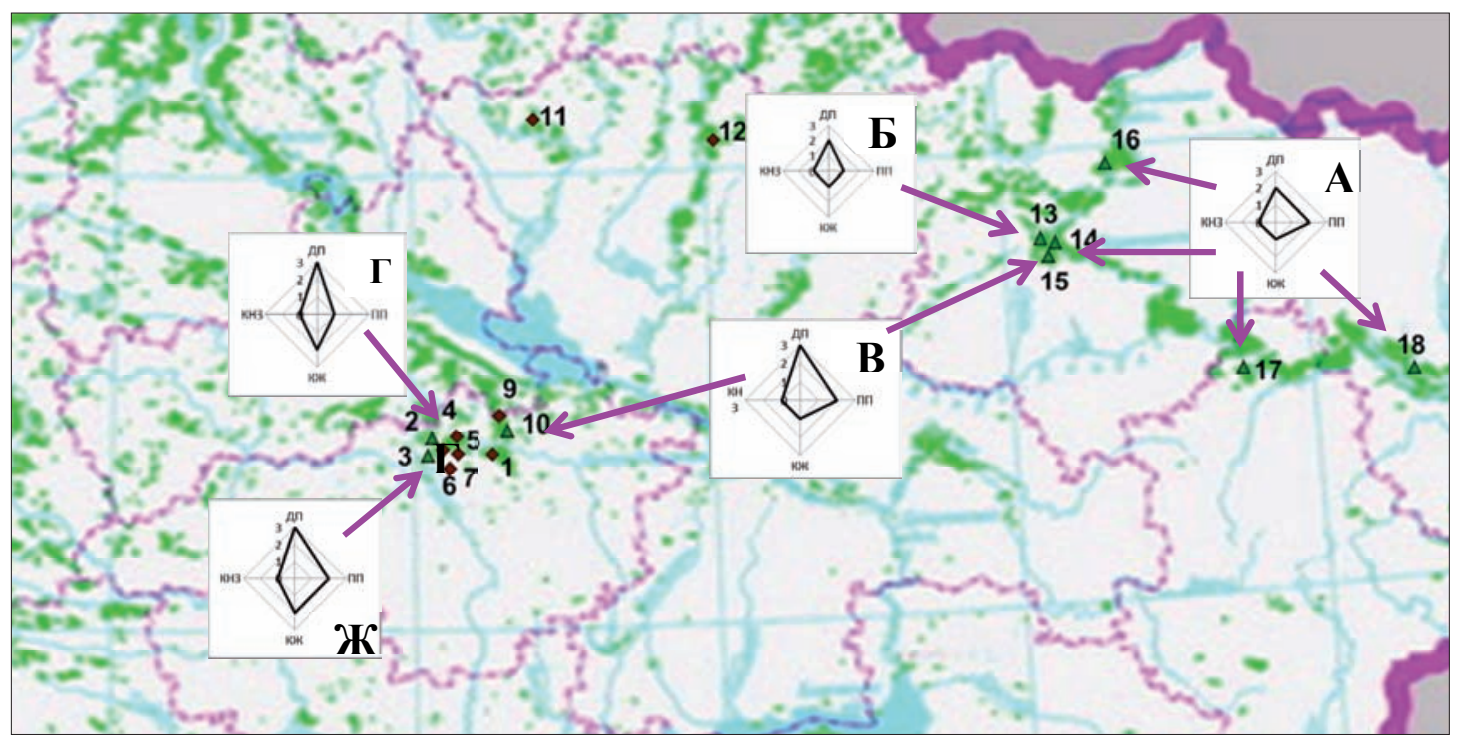

Рис. 7. Морфотипи природних мікропопуляцій Quercus robur L.

Звичайно, отримані результати дещо попередні i дослідження варто продовжити, залучивши більшу кількість природних деревостанів і розширивши географію їхнього розташування.

Висновки. Аналіз показників довжини плодоніжки у Лісостепу і Степу України засвідчив, що у природних деревостанах генетичних резерватів Харківської, Донецької і Луганської областей переважали дерева із плодоніжками завдовжки 2,1$5,0 \mathrm{~cm}$, тоді як у деревостанах генетичних резерватів природного походження Кіровоградської області - 5,1-8,0 см. У деревостанах штучного походження на Кіровоградщині певної закономірності не виявлено. В трьох деревостанах переважали дерева 3 плодоніжками завдовжки 2,1-5 см, у трьох інших $5,1-8,0$ см, і лише в одному - 3 рівною часткою дерев обох цих груп. Рівень внутрішньопопуляційної мінливості - високий або дуже високий, міжпопуляційної - середній.

За прямизною плодоніжки суттєвих відмінностей між популяціями не виявлено, але відзначено певні особливості. Так, у природних деревостанах Харківщини переважали дерева із прямими плодоніжками, а на Кіровоградщині - зі злегка викривленими. Серед штучних насаджень були такі, в яких переважали дерева із прямими плодоніжками (п'ять деревостанів), з переважанням дерев зі злегка викривленими плодоніжками (два деревостани) та $з$ рівною часткою дерев обох цих груп (один деревостан). Рівень внутрішньопопуляційної мінливості - від високого до дуже високого, міжпопуляційної - переважно середній.

Відзначено, що в природних деревостанах Харківщини та Донеччини переважали дерева з одним 
жолудем на плодоніжці, тоді як у природних деревостанах Кіровоградщини частота трапляння дерев 3 одним та двома жолудями на плодоніжці приблизно однакова. У більшості штучних деревостанів Кіровоградщини переважали дерева 3 одним жолудем на плодоніжці.

У переважній більшості деревостанів не виявлено недорозвинених зав'язей на плодоніжках. Частка дерев у деревостані, на плодоніжках яких утворилося по одній недорозвиненій зав'язі, становила від 10,0 до 33,3\%. Рівень внутрішньопопуляційної мінливості - дуже високий, міжпопуляційної - середній.

Для природних деревостанів дуба звичайного в Харківській, Донецькій та Луганській областях характерне переважання дерев 3 відносно короткою прямою плодоніжкою і одним жолудем на ній, тоді як у Кіровоградській - середньої довжини із двома жолудями. Виявлено збільшення довжини плодоніжки та кількості жолудів на ній із просуванням у напрямку зі сходу на захід.

Штучним деревостанам притаманний вищий рівень мінливості за всіма показниками порівняно 3 природними.

\section{Список літератури}

Андреев В.Н. (1927-1928). Гомологические ряды некоторых Дубов. Труды. по прикладной ботанике, генетике и селекции, XVIII, 2, 371-454. [Andreev V.N. (1927-1928). Homological row of some Oak. Works in applied botany, genetics and breeding, $X V I I I(2), 371-454]$ (in Russian)

Кривошея А.Н. (1969). Фенологические формы и изменчивость морфологических признаков дуба обыкновенного. Труды Харьковского с.-х. ин-та им. В. В. Докучаева, 86(123), 111-117. [Krivosheya, A.N. (1969). Phenological forms and variability of morphological characters of common oak. Work of Kharkiv agrarian institute named after V.V. Dokuchaev, 86(123), 111-117] (in Russian)

Кучеревский В.В. (1988). Внутривидовая изменчивость и формовое разнообразие дуба обыкновенного в условиях юго-востока Украины: дис.... канд. с.-х. наук: 03.00.05. Донецк. [Kucherevsky, V. V. (1988). Intraspecific variability and form diversity of English oak under conditions of southeastern. Phd thesis of agricultural sciences: 03.00.05 Donetsk] (in Russian)

Лось С.А. (2009). Методичні підходи до вивчення індивідуальної мінливості дуба звичайного (Quercus robur L.) за морфологічними ознаками жіночих репродуктивних структур. Лісівництво $i$ агролісомеліорація, 115, 20-27. [Los, S. (2009). Methodic approach to investigation of English oak (Quercus robur L.) individual variability by morphology of female reproductive structures. Forestry and Forest Melioration, 115, 2027. Retrieved from http://dspace.nbuv.gov.ua/handle/1234 56789/16411] (in Ukrainian)
Лось С. А., Борисова В. В. (2002). Методичні підходи до вивчення мінливості дуба звичайного за морфологічними ознаками. Вісник Харківського національного аграр. ун-ту. №2. C. 74-79. [Los, S.A., \& Borysova, V. V. (2002). Methodological approaches to study variability of Quercus robur L. morphological traits. Bulletin Kharkiv National Agrarian University, 2, 74-79] (in Ukrainian)

Малеев В.П. (1936). Род Quercus. Флора СССР. М.Л.: Изд-во АН СССР, 322-353. [Maleev, V.P. (1936). Genus Quercus. Flora of the USSR. Moscow-Leningrad: Academy of Sciences of the USSR] (in Russian)

Мамаев С.А. (1972). Формы внутривидовой изменчивости древесных пород. Москва: Наука, 283 с. [Mamaev, S.A. (1972). Forms of intraspecific variability of tree species. Moscow: Sciences] (in Russian)

Мачинский А.С. (1927). О расах дуба. Лесоведение и лесоводство, 4, 34-66. [Machinskyy, A. S. (1927). About the races of the oak. Forest science and forestry, 4, 34-66] (in Russian)

Меницкий Ю.Л. (1984). Дубы Азии. Ленинград: Наука, 314 c. [Menitsky, Y.L. (1984). Oaks of Asia. Leningrad: Sciences] (in Russian)

Погребняк П.С. (1926). Опыт исследования расового состава Quercus robur L. (обыкновенного дуба) в Тростянецком лесничестве на Украине. Лесоведение и лесоводство, 3, 40-45. [Pogrebnyak, P.S. (1926). The experience of studying the racial composition of Quercus robur L. (English oak) in Trostyanetsky forestry in Ukraine. Forest science and forestry, 3, 40-45] (in Russian)

Семериков Л.Ф. (1986). Популяциионная структура древесных растений: на примере видов дуба Европейской части СССР и Кавказа. Москва: Наука, 140 c. [Semerikov, L.F. (1986). Population structure of woody plants: on the example of oak species of the European part of the USSR and the Caucasus. Moscow: Science] (in Russian)

Слепых А.А., Коршиков И.И. (2017). Плодоношение дуба черешчатого (Quercus robur L.) и формовое разнообразие желудей в природных и исскуственных дубравах Юго-востока Украины. Вісник ОНУ. Біологія, 22, 2(41), 21-37. [Slepykh, А. А., \& Korshikov, I. I. (2017). Fruiting of English oak (Quercus robur L.) and acorns forms diversity in natural and artificial oak forests of the South-East of Ukraine. Bulletin ONU. Biology, 22, 2(41), 21-37. https://doi.org/10.18524/20771746.2017.2 (41).113768] (in Russian)

Aykut, Y., Emel, U., \& Tekin, B.M. (2017). Morphological variability of evergreen oaks (Quercus) in Turkey. Bangladesh Journal of Plant Taxonomy, 24(1), 39-47. https://doi.org/10.3329/ bjpt.v24i1.33004

Cousens, J.E. (1965). The status of the pedunculate and sessile oaks in Britain. Watsonia, 6(3), 161-176. Retrieved from http://archive.bsbi.org.uk/Wats6p 161.pdf

Denk, T., Grimm, G.W., Manos, P., Deng, M., \& Hipp, A. (2017) An updated infrageneric classifi- 
cation of the oaks: review of previous taxonomic schemes and synthesis of evolutionary patterns. BioRxiv. https://doi.org/10.1101/168146

Dupouey, J.L. (1983). Analyse multivariable de quelques caractères morphologiques de populations de chênes (Quercus robur L. et Quercus petraea (Matt.) Liebl.) du Hurepoix. Annales des sciences forestières, 40(3), 265-282. [Dupouey, J.L. (1983). Multivariate analysis of some morphological characteristecs of oaks populations (Quercus robur L. and Quercus petraea (Matt.) Liebl.) in Hurepoix. Annals of Forest Sciences, 40(3), 265-282. https://doi.org/10.1051/forest:19830303] (in Franch)

Dupouey, J.L., \& Badeau, V. (1993). Morphological variability of oaks (Quercus robur L, Quercus petraea (Matt) Liebl, Quercus pubescens Willd) in northeastern France: preliminary results. Annales des sciences forestières, INRA/EDP Sciences, 50 (Suppl1), 35-40. Retrieved from https://hal.archivesouvertes.fr/hal-00882873/document

Enescu, C.M., Curtu, A.L., \& Șofletea, N. (2013). Is Quercus virgiliana a distinct morphological and genetic entity among European white oaks? Turkish Journal of Agriculture and Forestry, 37, 632-641. https://doi.org/10.3906/tar-1210-28

Enescu, C.M. (2017). A dichotomous determination key for autochthonous oak species from Romania. Journal of Horticulture, Forestry and Biotechnology, 21 (4), 58-62. Retrieved from https:// journal-hfb.usab-tm.ro/2017/Lucrari\%20PDF\%20 21(4)/12Enescu\%20Mihai.pdf

Los, S., \& Smashnuk, L. (2020). Morphological variability of Quercus robur L. plus trees and clones in Podillia. Proceedings of the Forestry Academy of Sciences of Ukraine, 20, 107-119. https://doi. org/10.15421/412010

Mehrnia, M., Nejadsattari, T., Assadi, M., \& Mehregan, I. (2013). Taxonomic study of the genus Quercus L. Sect. Quercus in the Zagros forests of Iran. The Iranian Journal of Botany. 19(1), 62-74. Retrieved from https://ijb.areeo.ac.ir/article_2996 10523c96a0a48a907218499756bfe8ad.pdf

Nixon, K. (1993). Infrageneric classification of Quercus (Fagaceae) and typification of sectional names. Annals of Forest Science, 50, 25-34. https://doi.org/10.1051/FOREST:19930701Corpus ID: 85381128

Nixon, K. C. (2002). The Oak (Quercus) Biodiversity of California and Adjacent Regions. USDA Forest Service Gen. Tech. Rep. PSW-GTR-184. Retrieved from https://www.fs.fed.us/psw/publications/documents/ gtr-184/001_Nixon.pdf

Rushton, B. (1993). Natural hybridization within the genus Quercus L. Annales des sciences forestières, 50, 73-90. Retrieved from https://hal.archivesouvertes.fr/hal-00882878/document

Tantray, Y., \& Wani, S. (2017). Genus Quercus: An Overview. International journal of advanced research in science engineering, 6, 08, 1880-1886.
Retrieved from https://www.researchgate.net/publication/327673412_Genus_Quercus_An_Overview

\section{Population variability of English oak (Quercus robur L.) reproductive organs morphological features in the Forest-Steppe and Steppe of Ukraine}

\author{
S. $\operatorname{Los}^{1}$
}

The results of population variability study for English oak (Quercus robur L.) by the peduncle length, its form and the number of acorns on it in Forest-steppe and Steppe are presented. 18 stands of natural and artificial origin (planted forest) in Kharkiv, Poltava, Luhansk, Donetsk and Kirovograd, regions were studied. The stands of natural origin are represented by forest genetic reserves, artificial - mostly forest seed stands. Samples of peduncles were harvested under the crown of trees in the amount of 30-100 pieces (depending on the acorn harvest) in each observed plot. To compare micropopulations by a set of morphological indicators, a graphical method of constructing images of morphotypes in the MS Excel program was used. The levels of intra- and interpopulation variability on all features were determined.

The analysis of peduncle length showed that in natural stands of Kharkiv, Donetsk and Luhansk regions dominated trees with peduncle length 2.1$5.0 \mathrm{~cm}$, while in stands of natural origin of Kirovograd region - the trees with peduncle length $5.1-8.0 \mathrm{~cm}$. Any pattern was found in the artificial stands in Kirovograd region.

The regional peculiarities regarding the straightness of peduncles were revealed: trees with straight peduncles predominated in the natural stands of Kharkiv region. and in the Kirovograd region - with slightly distorted. Artificial plantations were dominated by trees with straight peduncles (five stands), with a predominance of trees with slightly curved peduncles (two stands) and with an equal share of trees in both groups (one stand).

It is found that in the natural stands of Kharkiv and Donetsk regions trees with one acorn on the peduncles predominated, while in the natural stands of Kirovohrad region the frequency of trees with one and two acorns on the peduncles is approximately the same. Most of the artificial stands in the Kirovohrad region were dominated by trees with one acorn on the peduncles.

Svitlana Los - Corresponding Member of the Forestry Academy of Sciences of Ukraine, PhD in Agricultural Sciences, Head of Laboratory of Forest Tree Breeding of Ukrainian Research Institute of Forestry and Forest Melioration named after G.M. Vysotsky, Pushkinska str., 86, Kharkiv, 61024, Ukraine. Tel.: 057-707-8077, +38-097-138-97-92. E-mail: svitlana_los@ukr.net ORCID: https://orcid.org/0000-0002-6341-2745 
In the vast majority of cases, underdeveloped ovaries are not observed on the peduncles. The share of trees with 1 underdeveloped ovary on the peduncles ranged from 10.0 to $33.3 \%$.

The level of intrapopulation variability for all indexes are from high to very high, interpopulation average.

Summarizing the obtained data, it should be noted that natural stands of English oak in Kharkiv, Donetsk and Luhansk regions are characterized by a predominance of trees with relatively short straight peduncles and one acorn on it, while in Kirovograd with medium length with two acorns. An increase in the length of the peduncle and the number of acorns on it in the direction from east to west. Artificial stands are characterized by a higher level of variability in all respects compared to natural.

Key words: population; peduncle; acorn; ovary; variability; mark; morphotype.

\section{Популяционная изменчивость морфологических признаков женских репродуктивных органов Quercus robur $L$. в Лесостепи и Степи Украины}

\section{C. А. Лось ${ }^{1}$}

Представлены результаты изучения популяционной изменчивости Quercus robur L. по длине плодоножки, ее форме и количеству желудей на ней в Лесостепи и Степи. Исследовано 18 древостоев природного и искусственного происхождения в Харьковской, Полтавской, Луганской, Донецкой и Кировоградской областях. Древостои природного происхождения представлены лесными генетическими резерватами, искусственного - преимущественно постоянными лесосеменными участками. Образцы плодоножек были заготовлены под кронами деревьев в количестве 30-100 штук в каждом обследованном выделе, в зависимости от урожая желудей. Для сравнения микропопуляций по комплек-

\footnotetext{
Лось Светлана Анатольевна - член-корреспондент Лесной академии наук Украины, кандидат сельскохозяйственных наук, заведующий лабораторией селекции. Украинский научно-исследовательский институт лесного хозяйства и агролесомелиорации им. Г.Н. Высоцкого, ул. Пушкинская, 86, г. Харьков, 61024, Украина. Тел.: 057-707-80-77, +38-097138-97-92. E-mail: svitlana_los@ukr.net ORCID: https://orcid. org/0000-0002-6341-2745
}

су морфологических показателей использован графический метод построения изображений морфотипов в программе MC EXEL. Определены уровни внутри- и межпопуляционной изменчивости по всем признакам.

Анализ длины плодоножек показал, что в естественных древостоях Харьковской, Донецкой и Луганской областей преобладали деревья с плодоножками длиной 2,1-5,0 см, тогда как в древостоях естественного происхождения Кировоградской области - 5,1-8,0 см. В искусственных насаждениях на Кировогращине определенной закономерности не установлено.

Выявлены региональные особенности относительно прямизны плодоножек: в природных насаждениях Харьковщины преобладали деревья с прямыми плодоножками, а в Кировоградской - со слегка изогнутыми. Среди искусственных насаждений были такие, в которых преобладали деревья с прямыми плодоножками (пять древостоев), с преобладанием деревьев со слегка изогнутыми плодоножками (два древостоя) и с равной долей деревьев обеих этих групп (один древостой).

Отмечено, что в природных древостоях Харьковщины и Донетчины преобладали деревья с одним желудем на плодоножке, тогда как в природных древостоях Кировоградщины частота встречаемости деревьев с одним и двумя желудями на плодоножке примерно одинакова. В большинстве искусственных насаждений Кировоградщины преобладали деревья с одним желудем на плодоножке. В подавляющем большинстве случаев недоразвитых завязей на плодоножках не отмечено. Доля деревьев, на плодоножках которых наблюдалось по одной недоразвитой завязи, составляла от 10,0 до $33,3 \%$.

Уровень внутрипопуляционной изменчивости по всем показателям - от высокого до очень высокого, межпопуляционной - средний.

Обобщая полученные данные следует отметить, что природные древостои дуба обыкновенного в Харьковской, Донецкой и Луганской областях характеризуются преобладанием деревьев с относительно короткой прямой плодоножкой и одним желудем на нем, тогда как в Кировоградской средней длины с двумя желудями. Отмечено увеличение длины плодоножки и количества желудей на нем в направлении с востока на запад. Искусственным древостоям присущ высокий уровень изменчивости по всем показателям по сравнению с природными.

Ключевые слова: популяция; плодоножка; желудь; завязь; изменчивость; балл, морфотип. 